\title{
Associations between new and old anthropometric indices with type 2 diabetes mellitus and risk of metabolic complications: a cross-sectional analytical study
}

\author{
Associação de índices antropométricos novos e antigos com diabetes melito tipo $2 e$ \\ risco de complicações metabólicas: um estudo analítico de corte transversal
}

Parichehr Amiri', Ahmad Zare Javid ${ }^{2}$ Leila Moradi ${ }^{3}$, Neda Haghighat ${ }^{4}$, Rahim Moradi ${ }^{5}$, Hossein Bavi Behbahani ${ }^{1}$ Milad Zarrin', Hadi Bazyar' ${ }^{1}$ (D)

\begin{abstract}
Background: Obesity can increase the risk of diabetes mellitus and complications associated with it. Objectives: The aim of this study was to estimate the associations between new and old anthropometric indices and the risk of type 2 diabetes mellitus (T2DM) and its metabolic complications. Methods: In this cross-sectional analytical study, 110 T2DM subjects and 110 healthy controls were selected by convenience sampling. Metabolic factors were evaluated including the atherogenic index of plasma (AIP), glycemic status, lipid profile, blood pressure, kidney indices, new anthropometric indices (abdominal volume index [AVI], body shape index [ABSI], lipid accumulation product [LAP], body adiposity index [BAI], and conicity index [Cl]), and old anthropometric indices (weight, body mass index [BMI], and waist and hip circumference [WC and HC]). Results: Significant positive correlations were observed between AVI, LAP, and $\mathrm{BAI}$ and fasting blood glucose and HbA1c in the T2DM group ( $<0.001$ for all associations). The odds ratio (OR) for T2DM elevated significantly with increasing BMI (OR: 1.30, 95\% Cl: 1.20-1.42), LAP (OR: 1.20, 95\% Cl: 1.13-1.27), and BAI (OR: 1.32, 95\% Cl: 1.21-1.43). The indices AVI (OR: 1.90, 95\% Cl: 1.57-2.29), LAP (OR: 1.19, 95\% Cl: 1.13-1.27), BAI (OR: 1.19, 95\% Cl: 1.12-1.26), WC (OR: 1.29, 95\% Cl: 1.18, 1.42), and HC (OR: 1.07, 95\% Cl: 1.01, 1.14) significantly increased the risk of metabolic syndrome (MetS). Conclusions: Associations were identified between obesity indices and diabetes. These indices could be used in clinical practice for evaluation and control of T2DM.
\end{abstract}

Keywords: anthropometry; obesity; type 2 diabetes mellitus; measures of association; exposure; risk or outcome.

\begin{abstract}
Resumo
Contexto: A obesidade pode aumentar o risco de diabetes melito e complicações associadas. Objetivos: $\bigcirc$ objetivo deste estudo foi estimar a associação de índices antropométricos novos e antigos com o risco de diabetes melito tipo 2 (DM2) e suas complicações metabólicas. Métodos: Neste estudo analítico transversal, 110 indivíduos com DM2 e 110 controles saudáveis foram selecionados por amostragem de conveniência. Foram avaliados os fatores metabólicos, incluindo índice aterogênico plasmático, estado glicêmico, perfil lipídico, pressão arterial, índices renais, índices antropométricos novos [índice de volume abdominal (AVI), índice de formato corporal (ABSI), produto de acumulação lipídica (LAP), índice de adiposidade corporal (BAI) e índice de conicidade (CI)] e índices antropométricos antigos [peso, índice de massa corporal (IMC), circunferência de cintura e quadril]. Resultados: Foi observada uma correlação positiva significativa de AVI, LAP e BAI com glicemia de jejum e hemoglobina glicada no grupo DM2 (p para todos < 0,001). A odds ratio (OR) do grupo DM2 foi significativamente elevada com aumento de IMC [OR: 1,30, intervalo de confiança (IC) de 95\%: 1,20-1,42], LAP (OR: 1,20, IC95\%: 1,13-1,27) e BAI (OR: 1,32, IC95\%: 1,21-1,43). Os índices AVI (OR: 1,90, IC95\%: 1,57-2,29), LAP (OR: 1,19, IC95\%: 1,13-1,27), BAI (OR: 1,19, IC95\%: 1,12-1,26), WC (OR: 1,29, IC95\%: 1,18-1,42) e HC (OR: 1,07, IC95\%: 1,01-1,14) aumentaram significativamente o risco de síndrome metabólica. Conclusões: Foi reconhecida uma associação entre índices de obesidade e diabetes. Esses índices podem ser usados na prática clínica para avaliação e controle do DM2.
\end{abstract}

Palavras-chave: antropometria; obesidade; diabetes melito tipo 2; medidas de associação; exposição; risco ou resultado.

How to cite: Amiri P, Javid AZ, Moradi L, et al. Associations between new and old anthropometric indices with type 2 diabetes mellitus and risk of metabolic complications: a cross-sectional analytical study. J Vasc Bras. 2021;20:e20200236. https://doi.org/10.1590/1677-5449.200236

\footnotetext{
${ }^{1}$ Ahvaz Jundishapur University of Medical Sciences, Student Research Committee, Ahvaz, Iran.

${ }^{2}$ Ahvaz Jundishapur University of Medical Sciences, School of Allied Medical Sciences, Department of Nutrition, Ahvaz, Iran.

${ }^{3}$ Ahvaz Jundishapur University of Medical Sciences, Health Research Institute, Diabetes Research Center, Ahvaz, Iran.

${ }^{4}$ Shiraz University of Medical Sciences, Laparoscopy Research Center, Shiraz, Iran.

${ }^{5}$ Ahvaz Jundishapur University of Medical Sciences, School of Medicine, Department of Clinical Biochemistry, Ahvaz, Iran.

Financial support: Student Research Committee of Ahvaz Jundishapur University of Medical Sciences (97s42)

Conflicts of interest: No conflicts of interest declared concerning the publication of this article.

Submitted: December 23, 2020. Accepted: August 02, 2021
} 


\section{INTRODUCTION}

Type 2 diabetes mellitus (T2DM) is a chronic disease characterized by abnormal blood glucose levels. It mainly develops when insulin secretion or action are impaired. ${ }^{1}$ The International Diabetes Federation (IDF) stated that 1 in 11 adults (415 million) were diabetic in 2015. According to the IDF's estimate, the global prevalence of diabetes mellitus (DM) may be more than 642 million people by $2040 .^{2}$

$\mathrm{DM}$ and its complications are crucial health concerns which should be considered. Most DM patients experience at least one complication. ${ }^{3}$ Complications can be categorized as microvascular (nephropathy, retinopathy, and neuropathy) or macrovascular (peripheral vascular disease, coronary artery disease, and cerebrovascular disease). T2DM usually occurs within the context of the metabolic syndrome (MetS), which is a cluster of conditions including abdominal obesity, hyperlipidemia, and hypertension. These factors can also act to promote macrovascular complications. All complications are responsible for DM-related morbidity and mortality. ${ }^{4}$

A complicated unknown interaction between environmental agents (sedentary life style, unhealthy diets, stress, obesity, etc.) and genetic factors (ethnic and racial differences, family history, etc.) contributes to the onset and progression of T2DM. ${ }^{5-7}$ On the other hand, the prevalence rates of obesity and T2DM are increasing simultaneously, which suggest that presence of obesity is a major risk factor for T2DM. ${ }^{8}$ Based on prior studies, obese subjects have altered levels of hormones, proinflammatory cytokines, non-esterified fatty acids, and other elements which are associated with insulin resistance and can lead to development of T2DM. ${ }^{9}$ In particular, studies indicate that there is a strong relationship between abdominal or visceral obesity and metabolic abnormalities. ${ }^{10}$ The risk of developing T2DM is 3 to 5 times greater in patients with MetS. ${ }^{11}$ Therefore, it is essential to assess the relationship between anthropometric indices and DM risk.

There are several anthropometric methods for measuring central and general obesity. As a common indicator of general obesity, body mass index (BMI) is identified as an important risk factor for T2DM. Indicators of abdominal obesity such as waist circumference (WC) and waist-to-hip ratio (WHR) are also considered as predictors of T2DM risk, independent of BMI. ${ }^{12}$ However, these traditional anthropometric measures do not discriminate visceral and subcutaneous fat. ${ }^{13}$ Furthermore, there are no ideal measurements to evaluate obesity, particularly when used to assess disease risk.

New anthropometric indices have been recently proposed that are easily applicable, low cost, and able to identify body fat distribution. These new anthropometric indices include a body shape index (ABSI), the adiposity volume index (AVI), the body adiposity index (BAI), the lipid accumulation product index (LAP), and the conicity index (CI). ${ }^{14}$ However, the correlations between these new indices and risk of T2DM and metabolic disturbances have not been completely studied. The ability to evaluate patients at risk is essential to ensure implementation of the most appropriate treatment strategies. The aim of the present study was to evaluate the associations between new and old anthropometric indices and risk of T2DM and of its metabolic complications.

\section{METHODS}

\section{Participants}

This cross-sectional analytical study was conducted from February 2019 to September 2019. In this study, 120 T2DM patients who had been referred to the Endocrinology and Metabolism clinic at Golestan Hospital, Ahvaz Jundishapur University of Medical Science, were enrolled on the study based on inclusion criteria (willingness to participate in the study, male and females with DM for more than 5 years, aged between 18 and 60 years) using a convenience sampling method. Lactating and pregnant women, smokers, alcohol consumers, patients with insulin injection, patients with other chronic diseases, and patients using antibiotics, immunosuppressive medications, or dietary supplements were excluded from the study. Also, 120 healthy controls (matched for sex and age and free from DM) were chosen from the same center using a convenience sampling method simultaneously with the case group. Exclusion criteria for the control group were similar to those for the case group.

\section{Calculation of Metabolic Syndrome (MetS)}

The prevalence of MetS was determined among the population in our study. According to the International Diabetes Federation (IDF) criteria for the Iranian population, MetS was defined as existence of central adiposity or waist circumference (WC) $\geq 95 \mathrm{~cm}$ for both genders (according to the Iranian National Committee of Obesity); ${ }^{15}$ plus two or more of the following four factors: high serum triglyceride concentration $(\geq 150 \mathrm{mg} / \mathrm{dL})$; low serum high-density lipoprotein cholesterol (HDL-c) ( $<50 \mathrm{mg} / \mathrm{dL}$ for women and $<40 \mathrm{mg} / \mathrm{dL}$ for men); high fasting blood sugar (FBS) $(\geq 100 \mathrm{mg} / \mathrm{dL})$, and high blood pressure $(\geq 130 / 85 \mathrm{~mm} \mathrm{Hg}){ }^{16,17}$

\section{Ethics approval}

Written informed consent was obtained from all participants at the beginning of the study. The research protocol was in accordance with the Declaration of Helsinki guidelines. The ethics committee at Ahvaz 
Jundishapur University of Medical Sciences approved the study (Ethical Code: IR.AJUMS.REC.1397.906).

\section{Measurement of new and old anthropometric indices}

Height, weight, WC, and hip circumference (HC) were measured by a trained nutritionist. A Seca scale was used for measuring weight (light clothing without shoes, precision of $0.5 \mathrm{~kg}$ ). Height was measured with a wall-mounted meter (precision of $0.1 \mathrm{~cm}$ ). WC (the distance between the iliac crest and the rib at the end of exhalation), and HC (at the level of the widest circumference over the greater trochanters) were measured using a non-elastic tape.

The anthropometric indices were calculated using the following equations (Equations 1-8). ${ }^{13,18}$

$$
\begin{aligned}
& \text { Body mass index }(\mathrm{BMI})=\frac{\text { weight }(\mathrm{kg})}{\text { height }^{2}} \\
& \text { Waist }- \text { to }- \text { hip ratio }(\mathrm{WHR})=\frac{\mathrm{WC}(\mathrm{cm})}{\mathrm{HC}(\mathrm{cm})} \\
& \text { A body shape index }(\mathrm{ABSI})=\frac{\mathrm{wc}}{\text { height }^{1 / 2} \times \mathrm{BMI}^{2 / 3}} \\
& \text { Abdominal volume index }(\mathrm{AVI})=\left[2\left(\mathrm{WC}^{2}\right)+0.7\left(\text { waist }^{2} \text { hip }\right)^{2}\right] / 1000 \\
& \text { Body adiposity index }(\mathrm{BAI})=\frac{\text { hip }^{1.5}}{\text { height }^{1.5}} \\
& \text { Conicity index }(\mathrm{CI})=\frac{\mathrm{WC}(\mathrm{m})}{0.109 \sqrt{ } \frac{\mathrm{weight}(\mathrm{kg})}{\text { height }(\mathrm{m})}} \\
& \text { LAP for men }=[\mathrm{WC}(\mathrm{cm})-65] \times[\text { triglyceride }(\mathrm{mM})] \\
& \text { LAP for women }=[\mathrm{WC}(\mathrm{cm})-58] \times[\text { triglyceride }(\mathrm{mM})]
\end{aligned}
$$

Measurement of mean arterial pressure (MAP), pulse pressure (PP), and physical activity (PA)

The international physical activity questionnaire (IPAQ) was used to evaluate physical activity (PA).${ }^{19}$ Blood pressure was measured using a mercury sphygmomanometer after 10 minutes at rest. Pulse pressure (PP) and mean arterial pressure (MAP) were computed according to the following equations (Equations 9 and 10); ${ }^{20}$

$$
\begin{aligned}
& \mathrm{PP}(\mathrm{mmHg})=S B P(\mathrm{mmHg})-D B P(\mathrm{mmHg}) \\
& \operatorname{MAP}(\mathrm{mmHg})=[\mathrm{SBP}+(2 \times \mathrm{DBP})] / 3
\end{aligned}
$$

\section{Biochemical measurements}

A blood sample $\left(5^{\mathrm{cc}}\right)$ was obtained after an overnight fast. Serum levels of metabolic parameters were assessed by an enzymatic method using standard kits (Pars Azmon Co. kit, Tehran, Iran). Hemoglobin A1C (HbAlc) levels were evaluated using high-performance liquid chromatography (HPLC). A urine sample was also collected over a 24-hour period. Micro-albuminuria was defined as levels of albumin ranging from 30 to $300 \mathrm{mg}$ in a 24-hour urine collection.

Low density lipoprotein (LDL-c), very low density lipoprotein (VLDL-c), atherogenic index of plasma (AIP), and estimated glomerular filtration rate (eGFR) were calculated according to the following equations (Equations 11-14); ;1,22

LDL-c $(\mathrm{mg} / \mathrm{dL})=$ Total cholesterol $(\mathrm{mg} / \mathrm{dL})-$ Triglycerides
$(\mathrm{mg} / \mathrm{dL}) / 5(\mathrm{VLDL}-\mathrm{c})-$ HDL-c $(\mathrm{mg} / \mathrm{dL})$

$V L D L-c=$ Triglycerides $(m g / d l) / 5$

$\mathrm{AIP}=\log \frac{\text { Triglycerides }}{\mathrm{HDL}}$

eGFR $\left(\mathrm{mL} /\right.$ min per $\left.1.73 \mathrm{~m}^{2}\right)=186 \times(\text { SerumCreatinine })^{-1.154} \times$

$(\text { Age })^{-0.203} \times(0.742$ if female $) \times(1.210$ if African-American $)$

\section{Sample size}

Based on the study by Rahmanian et al., and considering blood pressure as the main variable ( $\alpha=0.05$ and $\beta=0.1$ ), the sample size was calculated as 120 people in each group. ${ }^{23}$

\section{Statistical analysis}

In this study, new anthropometric indices (AVI, ABSI, LAP, BAI, and CI), and old anthropometric indices (weight, BMI, WC, and $\mathrm{HC}$ ) were considered as independent variables and metabolic parameters (fasting blood glucose [FBG], glycosylated hemoglobin [HbA1C], triglycerides [TG], total cholesterol [CHOL], HDL-c, LDL-c, VLDL-c, eGFR, blood urea nitrogen [BUN], creatinine [Cr], SBP, DBP, MAP, PP, and AIP) and the risk of DM and MetS were considered as dependent variables. Also, metabolic syndrome, gender, and education were considered as categorical variables and metabolic parameters (FBG, $\mathrm{HbA} 1 \mathrm{C}$, TG, CHOL, HDL-c, LDL-c, VLDL-c, eGFR, BUN, $\mathrm{Cr}$, SBP, DBP, MAP, PP, and AIP) were considered as continuous variables. Normality of data was checked with the Kolmogorov-Smirnov test. Parametric variables are expressed as mean \pm standard deviation (SD). The $t$ test for independent samples was applied to compare means (SD) of normally distributed parameters. Correlations between anthropometric indices and metabolic parameters were assessed using the Pearson correlation test. Odds ratios (ORs) and 
their $95 \%$ confidence intervals (CIs) were reported using Logistic regression tests. Data were analyzed using SPSS version 19 for Windows (PASW Statistics). P-values less than 0.05 were considered significant.

\section{RESULTS}

\section{General characteristics}

Ten people from each group were excluded from the study because of a lack of study conditions and unwillingness to participate. A total of 220 participants (110 T2DM patients and 110 healthy controls) were involved in this study. The mean ages of the participants in the T2DM and control groups were respectively $50.65 \pm 5.31$ and $51.62 \pm 5.6$ years. The general characteristics of participants are shown in Table1.

\section{Comparison of anthropometric indices and metabolic parameters between the T2DM and healthy groups}

Weight, BMI, WHR, WC, HC, and waist-to-height ratio were significantly greater in the T2DM group than in the healthy group ( $\mathrm{p}<0.001$ for all comparisons). The T2DM group had significantly lower physical activity compared

Table 1. Characteristics of the subjects in the healthy and T2DM groups.

\begin{tabular}{|c|c|c|c|}
\hline Variables & Healthy group & Diabetic group & P-value \\
\hline Age (y) & $51.62 \pm 5.6$ & $50.65 \pm 5.31$ & 0.18 \\
\hline \multicolumn{4}{|l|}{ Gender } \\
\hline Female (N) (\%) & $72(49)$ & $75(51)$ & $0.66^{*}$ \\
\hline Male (N) (\%) & $38(52.1)$ & $35(47.9)$ & \\
\hline \multicolumn{4}{|l|}{ Education } \\
\hline Illiterate - elementary (N) (\%) & $64(43.8)$ & $82(56.2)$ & $0.056^{*}$ \\
\hline Middle school (N) (\%) & $24(60)$ & $16(40)$ & \\
\hline High school (N) (\%) & $13(59.1)$ & $9(40.9)$ & \\
\hline College (N) (\%) & $9(75)$ & $3(25)$ & \\
\hline Total & 110 & 110 & \\
\hline Weight (kg) & $66.79 \pm 7.91$ & $75.94 \pm 11.52$ & $<0.001$ \\
\hline Height $(\mathrm{cm})$ & $165.78 \pm 8.83$ & $164.18 \pm 10.87$ & 0.23 \\
\hline Body mass index $\left(\mathrm{kg} / \mathrm{m}^{2}\right)$ & $24.45 \pm 3.57$ & $28.22 \pm 3.82$ & $<0.001$ \\
\hline Waist circumference $(\mathrm{cm})$ & $73.81 \pm 4.40$ & $103.46 \pm 8.73$ & $<0.001$ \\
\hline Hip circumference $(\mathrm{cm})$ & $95.27 \pm 4.05$ & $107.73 \pm 8.83$ & $<0.001$ \\
\hline Waist-to-hip ratio & $0.77 \pm 0.04$ & $0.96 \pm 0.07$ & $<0.001$ \\
\hline Waist-to-height ratio & $0.44 \pm 0.03$ & $0.63 \pm 0.06$ & $<0.001$ \\
\hline Physical activity (MET-min/week) & $961.12 \pm 548.26$ & $286.93 \pm 154.77$ & $<0.001$ \\
\hline Fasting blood glucose (mg/dL) & $87.69 \pm 7.78$ & $165.17 \pm 31.39$ & $<0.001$ \\
\hline Hemoglobin A1c \% & $4.84 \pm 0.46$ & $8.34 \pm 1.31$ & $<0.001$ \\
\hline Triglycerides (mg/dL) & $156.86 \pm 62.22$ & $148.94 \pm 38.29$ & 0.25 \\
\hline Total cholesterol (mg/dl) & $167.29 \pm 64.89$ & $159.37 \pm 34.55$ & 0.26 \\
\hline High-density lipoprotein cholesterol (mg/dl) & $47.50 \pm 10.43$ & $42.55 \pm 10.28$ & $<0.001$ \\
\hline Low-density lipoprotein cholesterol (mg/dl) & $89.27 \pm 38.37$ & $98.18 \pm 41.76$ & 0.1 \\
\hline Very low-density lipoprotein cholesterol (mg/dl) & $31.37 \pm 12.44$ & $29.78 \pm 7.65$ & 0.25 \\
\hline Low-density/high-density lipoprotein cholesterol & $2.04 \pm 1.07$ & $2.45 \pm 1.36$ & 0.01 \\
\hline Atherogenic index of plasma & $0.49 \pm 0.22$ & $0.54 \pm 0.15$ & 0.08 \\
\hline Estimated glomerular filtration rate $\left(\mathrm{mL} / \mathrm{min} / 1.73 \mathrm{~m}^{2}\right)$ & $80.23 \pm 16.56$ & $79.62 \pm 18.32$ & 0.79 \\
\hline Blood urea nitrogen $(\mathrm{mg} / \mathrm{dL})$ & $12.69 \pm 2.23$ & $13.34 \pm 3.01$ & 0.07 \\
\hline Creatinine $(\mathrm{mg} / \mathrm{dL})$ & $0.80 \pm 0.14$ & $0.86 \pm 0.15$ & 0.006 \\
\hline Albuminuria (mg/24h) & $5.60 \pm 2.09$ & $10.62 \pm 4.29$ & $<0.001$ \\
\hline Systolic blood pressure $(\mathrm{mmHg})$ & $118.72 \pm 9.96$ & $125.36 \pm 13.11$ & $<0.001$ \\
\hline Diastolic blood pressure $(\mathrm{mmHg})$ & $73.45 \pm 7.34$ & $76.18 \pm 8.34$ & 0.01 \\
\hline Mean arterial pressure $(\mathrm{mmHg})$ & $88.54 \pm 7.41$ & $92.57 \pm 8.40$ & $<0.001$ \\
\hline Pulse pressure $(\mathrm{mmHg})$ & $45.27 \pm 7.98$ & $49.18 \pm 12.20$ & 0.005 \\
\hline A body shape index $\left(\mathrm{m}^{11 / 6} \mathrm{Kg}^{-2 / 3}\right)$ & $0.036 \pm 0.01$ & $0.037 \pm 0.01$ & 0.35 \\
\hline Abdominal volume index & $10.93 \pm 1.29$ & $21.56 \pm 3.54$ & $<0.001$ \\
\hline Conicity index & $1.06 \pm 0.08$ & $1.40 \pm 0.15$ & $<0.001$ \\
\hline Lipid accumulation product & $24.45 \pm 12.69$ & $73.43 \pm 26.25$ & $<0.001$ \\
\hline Body adiposity index $\left(\mathrm{Kg} / \mathrm{m}^{2}\right)$ & $26.87 \pm 4.01$ & $33.59 \pm 6.39$ & $<0.001$ \\
\hline \multicolumn{4}{|l|}{ Metabolic syndrome } \\
\hline Yes & $0(0)$ & $77(70)$ & $<0.001^{*}$ \\
\hline No & $110(100)$ & $33(30)$ & \\
\hline Total & $110(100)$ & $110(100)$ & \\
\hline
\end{tabular}

Values are expressed as means \pm SD. $P<0.05$ was considered as significant using the independent $t$ test for comparison between the two groups; ${ }^{*} P<0.05$ was considered as significant using the Chi-square test. 
with the healthy group $(\mathrm{p}<0.001)$. Except for ABSI, the other anthropometric indices including AVI, CI, LAP, and BAI were significantly lower in the healthy group than the T2DM group ( $\mathrm{p}<0.001$ for all comparisons). Also, HDL-c $(\mathrm{p}<0.001)$ was significantly lower and the LDL-c to HDL-c ratio $(\mathrm{p}=0.01)$ was significantly higher in T2DM patients than the healthy group. $\operatorname{SBP}(p<0.001)$, $\operatorname{DBP}(\mathrm{p}=0.01), \operatorname{MAP}(\mathrm{p}<0.001)$, and PP $(\mathrm{p}=0.005)$ were significantly higher in the T2DM group compared with the healthy group. The metabolic parameters eGFR, creatinine, and BUN did not significantly differ between the two groups ( $\mathrm{p} \geq 0.05$ ), whereas albuminuria was significantly higher in T2DM patients than in the healthy controls $(\mathrm{p}<0.001)$ (Table 1$)$.

\section{T2DM risk assessment according to new and old anthropometric indices}

LAP and BAI significantly increased the risk of T2DM even after adjustment for confounding factors (sex, age, physical activity, education, and medications) (OR: 1.21, 95\% CI: 1.06-1.37; $\mathrm{p}=0.003$ and OR: 1.33, 95\% CI: $1.10-1.62 ; \mathrm{p}=0.003$, respectively). AVI showed the greatest OR (OR: 28.38, 95\% CI: 0.99-812.80) for T2DM, followed by BAI (OR: 1.32, 95\% CI: 1.21-1.43) and LAP (OR: 1.20, 95\% CI: 1.13-1.27). In addition, the risk of T2DM was related to increasing weight, $\mathrm{HC}$, and $\mathrm{BMI}$ both before and after adjustment for variables including sex, age, physical activity, education, and medications. WC increased the risk of T2DM (OR: 2.95, 95\% CI: 1.02-8.55), but there was no significant difference after adjusting for confounding variables (Table 2 ).

\section{Correlation of new anthropometric indices with metabolic parameters in the T2DM group}

FBG was significantly positively correlated with waist-to-height ratio $(\mathrm{r}=0.75 ; \mathrm{p}<0.001), \mathrm{AVI}(\mathrm{r}=0.78$; $\mathrm{p}<0.001)$, LAP $(\mathrm{r}=0.74 ; \mathrm{p}<0.001)$, CI $(\mathrm{r}=0.7$;

Table 2. Odds ratios ( $95 \% \mathrm{Cl}$ ) for T2DM according to new and old anthropometric indices.

\begin{tabular}{|c|c|c|c|}
\hline Variables & $\operatorname{Or}(\mathrm{Cl})$ & B & ${ }^{*} P$-value \\
\hline \multicolumn{4}{|l|}{ Body adiposity index $\left(\mathrm{Kg} / \mathrm{m}^{2}\right)$} \\
\hline Model $1^{\mathrm{a}}$ & $1.32(1.21-1.43)$ & 0.27 & $<0.001$ \\
\hline Model $2^{b}$ & $1.34(1.23-1.46)$ & 0.29 & $<0.001$ \\
\hline $\begin{array}{l}\text { Model } 3^{c} \\
\text { Model } 4^{d}\end{array}$ & $\begin{array}{l}1.31(1.17-1.46) \\
1.33(1.10-1.62)\end{array}$ & $\begin{array}{l}0.27 \\
0.29\end{array}$ & $\begin{array}{r}<0.001 \\
0.003\end{array}$ \\
\hline \multicolumn{4}{|l|}{ Lipid accumulation product } \\
\hline Model $1^{\mathrm{a}}$ & $1.20(1.13-1.27)$ & 0.18 & $<0.001$ \\
\hline Model $2^{b}$ & $1.21(1.13-1.28)$ & 0.19 & $<0.001$ \\
\hline Model $3^{c}$ & $1.30(1.15-1.46)$ & 0.26 & $<0.001$ \\
\hline Model $4^{d}$ & $1.21(1.06-1.37)$ & 0.19 & 0.003 \\
\hline \multicolumn{4}{|l|}{ Abdominal volume index } \\
\hline Model $1^{\mathrm{a}}$ & $28.38(0.99-812.80)$ & 3.34 & 0.051 \\
\hline Model $2^{b}$ & $29.34(0.91-937.89)$ & 3.37 & 0.056 \\
\hline Model $3^{c}$ & $59.83(0.43-8206.14)$ & 4.09 & 0.10 \\
\hline Model $4^{d}$ & $54.09(0.29-10003.22)$ & 16.19 & 0.98 \\
\hline \multicolumn{4}{|l|}{ Weight } \\
\hline Model $1^{\mathrm{a}}$ & $1.10(1.06-1.13)$ & 0.09 & $<0.001$ \\
\hline Model $2^{b}$ & $1.10(1.06-1.14)$ & 0.09 & $<0.001$ \\
\hline Model $3^{c}$ & $1.08(1.03-1.13)$ & 0.08 & $<0.001$ \\
\hline Model $4^{d}$ & $1.16(1.04-1.30)$ & 0.15 & 0.006 \\
\hline \multicolumn{4}{|l|}{ Body mass index $(\mathrm{kg} / \mathrm{m} 2)$} \\
\hline Model $1^{\mathrm{a}}$ & $1.30(1.20-1.42)$ & 0.26 & $<0.001$ \\
\hline Model $2^{b}$ & $1.31(1.20-1.42)$ & 0.26 & $<0.001$ \\
\hline Model $3^{c}$ & $1.36(1.19-1.56)$ & 0.30 & $<0.001$ \\
\hline Model $4^{d}$ & $1.29(1.05-1.58)$ & 0.25 & 0.01 \\
\hline \multicolumn{4}{|l|}{ Waist circumference $(\mathrm{cm})$} \\
\hline Model $1^{\mathrm{a}}$ & $2.95(1.02-8.55)$ & 1.08 & 0.045 \\
\hline Model $2^{b}$ & $2.98(0.99-8.93)$ & 1.09 & 0.050 \\
\hline Model $3^{c}$ & $3.74(0.78-17.85)$ & 1.32 & 0.09 \\
\hline Model $4^{d}$ & $56.34(0.001-5.977 \mathrm{E})$ & 4.03 & 0.98 \\
\hline \multicolumn{4}{|l|}{ Hip circumference $(\mathrm{cm})$} \\
\hline Model $1^{\mathrm{a}}$ & $1.44(1.30-1.60)$ & 0.37 & $<0.001$ \\
\hline Model $2^{b}$ & $1.45(1.31-1.61)$ & 0.37 & $<0.001$ \\
\hline Model $3^{c}$ & $1.37(1.22-1.55)$ & 0.32 & $<0.001$ \\
\hline Model $4^{d}$ & $1.50(1.31-2.00)$ & 0.40 & 0.005 \\
\hline
\end{tabular}

${ }^{*} P<0.05$ statistically significant according to multivariate logistic regression; a. Model 1: unadjusted; b. Model 2: adjusted for age and gender; $c$. Model 3: adjusted for age, gender, education, and physical activity; d. Model 4: adjusted for age, gender, education, physical activity, and medications. 
$\mathrm{p}<0.001)$, and BAI $(\mathrm{r}=0.49 ; \mathrm{p}<0.001)$. HbA1c was significantly positively correlated with waistto-height ratio $(\mathrm{r}=0.74 ; \mathrm{p}<0.001)$, AVI $(\mathrm{r}=0.75$; $\mathrm{p}<0.001)$, LAP $(\mathrm{r}=0.73 ; \mathrm{p}<0.001)$, CI $(\mathrm{r}=0.75$; $\mathrm{p}<0.001)$, and BAI $(\mathrm{r}=0.46 ; \mathrm{p}<0.001)$. In the T2DM group, LDL-c was significantly positively correlated with waist-to-height ratio $(\mathrm{r}=0.15 ; \mathrm{p}=0.02)$, AVI $(\mathrm{r}=0.14 ; \mathrm{p}=0.02)$ and LAP $(\mathrm{r}=0.24 ; \mathrm{p}<0.001)$. LDL-c/HDL-c was significantly positively correlated with waist-to-height ratio $(\mathrm{r}=0.22 ; \mathrm{p}=0.001)$, AVI $(\mathrm{r}=0.21, \mathrm{p}=0.001), \operatorname{LAP}(\mathrm{r}=0.29 ; \mathrm{p}<0.001), \mathrm{CI}$ $(\mathrm{r}=0.15 ; \mathrm{p}=0.02)$ and BAI $(\mathrm{r}=0.14, \mathrm{p}=0.03)$. HDL-c was significantly negatively correlated with waist-to-height ratio $(\mathrm{r}=-0.23 ; \mathrm{p}<0.001)$, AVI $(\mathrm{r}=-0.22, \mathrm{p}=0.001), \operatorname{LAP}(\mathrm{r}=-0.24, \mathrm{p}<0.001)$, and $\mathrm{CI}(\mathrm{r}=-0.18, \mathrm{p}=0.005)$. The AIP was significantly positively correlated with LAP $(r=0.42, p<0.001)$. Also, triglycerides $(r=0.36 ; p<0.001)$, total cholesterol (TC) $(\mathrm{r}=0.16 ; \mathrm{p}=0.01)$, and VLDL-c $(\mathrm{r}=0.36$; $\mathrm{p}<0.001$ ) were significantly positively correlated with LAP. In addition, BUN was significantly positively correlated with waist-to-height ratio $(\mathrm{r}=0.16 ; \mathrm{p}=$ $0.01)$ and AVI $(r=0.14 ; p=0.03)$. Creatinine was significantly positively correlated with waist-to-height ratio $(\mathrm{r}=0.17 ; \mathrm{p}=0.01)$, AVI $(\mathrm{r}=0.20 ; \mathrm{p}=0.002)$, $\operatorname{LAP}(\mathrm{r}=0.14 ; \mathrm{p}<0.001)$ and $\mathrm{CI}(\mathrm{r}=0.14 ; \mathrm{p}=0.03)$. Albuminuria was significantly positively correlated with waist-to-height ratio $(\mathrm{r}=0.48 ; \mathrm{p}=<0.001)$, AVI $(\mathrm{r}=0.50 ; \mathrm{p}<0.001), \mathrm{LAP}(\mathrm{r}=0.44 ; \mathrm{p}<0.001)$, CI $(\mathrm{r}=0.49 ; \mathrm{p}<0.001)$, and BAI $(\mathrm{r}=0.35 ; \mathrm{p}<0.001)$. MAP was significantly positively correlated with waist-to-height ratio $(\mathrm{r}=0.25 ; \mathrm{p}=<0.001)$, AVI $(\mathrm{r}=0.24 ; \mathrm{p}<0.001), \operatorname{LAP}(\mathrm{r}=0.20 ; \mathrm{p}=0.033), \mathrm{CI}$ $(\mathrm{r}=0.20 ; \mathrm{p}=0.002)$ and BAI $(\mathrm{r}=0.25 ; \mathrm{p}=0.001)$. $\mathrm{PP}$ was positively correlated with waist-to-height ratio $(\mathrm{r}=0.18 ; \mathrm{p}=0.005)$, AVI $(\mathrm{r}=0.16 ; \mathrm{p}=0.01), \mathrm{LAP}$ $(\mathrm{r}=0.15, \mathrm{p}=0.01), \mathrm{CI}(\mathrm{r}=0.14, \mathrm{p}=0.03)$, and BAI $(\mathrm{r}=0.17, \mathrm{p}=0.01)$. SBP was positively correlated with waist-to-height ratio $(r=0.27 ; p=<0.001)$, AVI $(\mathrm{r}=0.26 ; \mathrm{p}<0.001), \operatorname{LAP}(\mathrm{r}=0.22 ; \mathrm{p}=0.001), \mathrm{CI}$ $(\mathrm{r}=0.22 ; \mathrm{p}=0.001)$, and BAI $(\mathrm{r}=0.25 ; \mathrm{p}<0.001)$. DBP was positively correlated with waist-to-height ratio $(r=0.17 ; p=0.009)$, AVI $(r=0.18 ; p=0.007)$, $\operatorname{LAP}(r=0.13 ; \mathrm{p}=0.03), \mathrm{CI}(\mathrm{r}=0.14 ; \mathrm{p}=0.04)$, and BAI $(r=0.15 ; p=0.01)$. No significant correlations were found between ABSI and metabolic factors (Table 3).

\section{New and old anthropometric indices and the risk of Metabolic Syndrome (MetS)}

Seventy-seven out of 110 T2DM patients (70\%) had MetS based on the IDF criteria for the Iranian population, whereas there was no MetS in the healthy group $(\mathrm{p}<0.001)($ Table 1$)$. The OR for MetS increased significantly with AVI (OR: 1.90, 95\% CI: 1.57-2.29, $\mathrm{p}<0.001$ ), LAP (OR: 1.19, 95\% CI: 1.13-1.27, $\mathrm{p}<0.001$ ), and BAI (OR: 1.19, 95\% CI: 1.12-1.26, $\mathrm{p}<0.001$ ). Also, after adjusting for confounding factors (sex, age, physical activity, education, and medications), the results did not change in terms of significance $(p<0.05)$. Furthermore, the OR for MetS increased significantly with weight (OR: $1.05,95 \%$ CI: 1.02, 1.08, p < 0.001), BMI (OR: 1.14, 95\% CI: 1.06, 1.23, p < 0.001), WC (OR: 1.28, 95\% CI: 1.19 , $1.38, \mathrm{p}<0.001$ ), and $\mathrm{HC}$ (OR: $1.19,95 \%$ CI: 1.13 , $1.25, \mathrm{p}<0.001)$. Also, after adjusting for confounding factors (sex, age, physical activity, education, and medications), the results reminded significant for WC (OR: 1.29, 95\% CI: 1.18, 1.42, $\mathrm{p}<0.001$ ), and HC (OR: 1.07, 95\% CI: 1.01, 1.14, p=0.09) (Table 4).

\section{DISCUSSION}

This study evaluated the relationship between new and old anthropometric indices and the risk of T2DM and its cardiometabolic complications. All anthropometric indices except ABSI were greater in patients with T2DM compared with the participants in the control group. AVI, LAP, and CI were strongly and BAI was moderately associated with FBS and HbA1c. These indices showed similar correlations with SBP, DBP, PP and MAP. Also, new anthropometric indices have predictive ability for risk of T2DM and MetS, similar to BMI. LAP, and BAI have equal chance of predicting T2DM in our study. Obesity as measured by these indices is more related to T2DM because abdominal obesity has been described as a stronger independent predictor, not only of cardiovascular events and mortality, but also of T2DM.

Regarding the ABSI, there was no significant difference between the two groups. Additionally, the ABSI did not significantly correlate with any components of the MetS. Similarly, Gomez et al.and Hardy et al., reported no relationship between ABSI and metabolic parameters. ${ }^{24,25}$ The ABSI was developed by Krakauer et al. who normalized WC to BMI and height. ${ }^{26}$ Although ABSI was significantly correlated with age and WC in the Gomez-Peralta et al., study, it seems not to be effective in relation to metabolic diseases. $^{24}$

In this study, the AVI was significantly correlated with glucose, lipid profile, blood pressure, and renal factors. The AVI formula is based on WC and WHR. In line with our findings, Guerrero-Romero et al. found that AVI was strongly related to impaired glucose tolerance (IGT) and T2DM. ${ }^{27}$ It also showed the highest OR values in their study, which is not consistent with our findings. ${ }^{27}$ Although the OR for MetS increased significantly with AVI, the OR for T2DM did not attain 


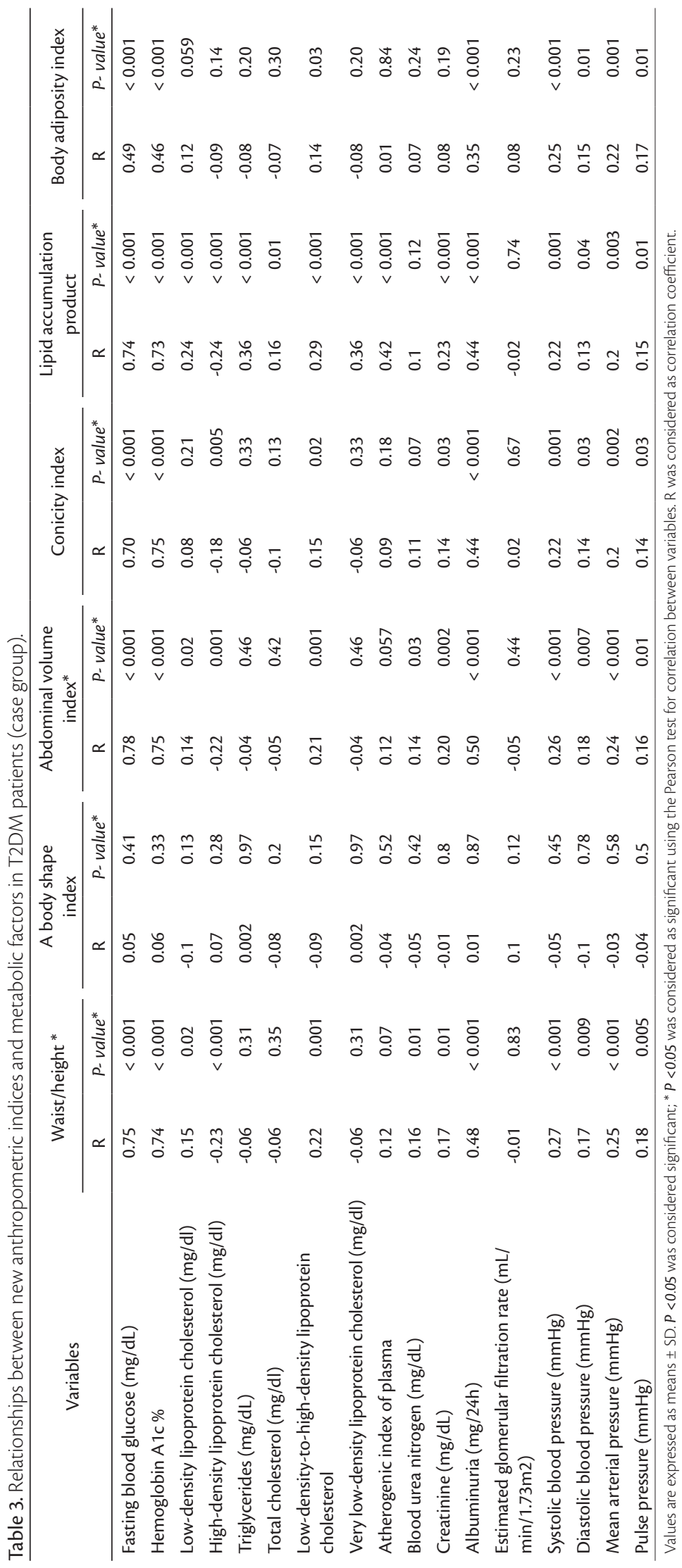


Table 4. Odds ratios $(95 \% \mathrm{Cl})$ for metabolic syndrome according to new and old anthropometric indices.

\begin{tabular}{|c|c|c|c|}
\hline Variable & $\operatorname{Or}(\mathrm{Cl})$ & B & *P-value \\
\hline \multicolumn{4}{|l|}{ Body adiposity index $\left(\mathrm{Kg} / \mathrm{m}^{2}\right)$} \\
\hline Model $1^{\text {a }}$ & $1.19(1.12-1.26)$ & 0.17 & $<0.001$ \\
\hline Model $2^{\text {b }}$ & $1.19(1.12-1.27)$ & 0.17 & $<0.001$ \\
\hline Model $3^{c}$ & $1.12(1.05-1.19)$ & 0.11 & $<0.001$ \\
\hline Model $4^{\mathrm{d}}$ & $1.09(1.01-1.17)$ & 0.08 & 0.01 \\
\hline \multicolumn{4}{|l|}{ Lipid accumulation product } \\
\hline Model $1^{\mathrm{a}}$ & $1.19(1.13-1.27)$ & 0.18 & $<0.001$ \\
\hline Model $2^{\mathrm{b}}$ & $1.20(1.13-1.28)$ & 0.18 & $<0.001$ \\
\hline Model 3' & $1.19(1.12-1.27)$ & 0.17 & $<0.001$ \\
\hline Model $4^{\mathrm{d}}$ & $1.21(1.06-1.37)$ & 0.19 & 0.003 \\
\hline \multicolumn{4}{|l|}{ Abdominal volume index } \\
\hline Model $1^{\mathrm{a}}$ & $1.90(1.57-2.29)$ & 0.64 & $<0.001$ \\
\hline Model $2^{\mathrm{b}}$ & $1.94(1.60-2.35)$ & 0.66 & $<0.001$ \\
\hline Model $3^{c}$ & $1.94(1.57-2.40)$ & 0.66 & $<0.001$ \\
\hline Model $4^{\mathrm{d}}$ & $1.97(1.58-2.46)$ & 0.68 & $<0.001$ \\
\hline \multicolumn{4}{|l|}{ Weight } \\
\hline Model $1^{\mathrm{a}}$ & $1.05(1.02,1.08)$ & 0.05 & $<0.001$ \\
\hline Model $2^{b}$ & $1.05(1.02,1.08)$ & 0.05 & $<0.001$ \\
\hline Model $3^{c}$ & $1.01(0.98,1.05)$ & 0.01 & 0.23 \\
\hline Model $4^{\mathrm{d}}$ & $1.00(0.96,1.04)$ & 0.002 & 0.90 \\
\hline \multicolumn{4}{|l|}{ Body mass index $\left(\mathrm{kg} / \mathrm{m}^{2}\right)$} \\
\hline Model $1^{\mathrm{a}}$ & $1.14(1.06,1.23)$ & 0.13 & $<0.001$ \\
\hline Model $2^{\mathrm{b}}$ & $1.14(1.06,1.23)$ & 0.13 & $<0.001$ \\
\hline Model $3^{c}$ & $1.06(0.98,1.16)$ & 0.06 & 0.11 \\
\hline Model $4^{\mathrm{d}}$ & $0.99(0.89,1.10)$ & -0.008 & 0.87 \\
\hline \multicolumn{4}{|l|}{ Waist circumference (cm) } \\
\hline Model $1^{\text {a }}$ & $1.28(1.19,1.38)$ & 0.25 & $<0.001$ \\
\hline Model $2^{\mathrm{b}}$ & $1.29(1.19,1.40)$ & 0.25 & $<0.001$ \\
\hline Model $3^{c}$ & $1.29(1.19,1.41)$ & 0.26 & $<0.001$ \\
\hline Model $4^{\mathrm{d}}$ & $1.29(1.18,1.42)$ & 0.26 & $<0.001$ \\
\hline \multicolumn{4}{|l|}{ Hip circumference $(\mathrm{cm})$} \\
\hline Model $1^{\text {a }}$ & $1.19(1.13,1.25)$ & 0.17 & $<0.001$ \\
\hline Model $2^{\mathrm{b}}$ & $1.20(1.14,1.26)$ & 0.18 & $<0.001$ \\
\hline Model $3^{c}$ & $1.13(1.07,1.19)$ & 0.12 & $<0.001$ \\
\hline Model $4^{\mathrm{d}}$ & $1.07(1.01,1.14)$ & 0.07 & 0.009 \\
\hline
\end{tabular}

${ }^{*} P<0.05$ statistically significant according to multivariate logistic regression; a. Model 1: unadjusted; b. Model 2: adjusted for age and gender; c. Model 3: adjusted for age, gender, education, and physical activity; d. Model 4: adjusted for age, gender, education, physical activity, and medications.

significance. In another study, Ehrampoush et al., evaluated the relationship between anthropometric indices and body fat content. They suggested that AVI is more accurate than the other indices for evaluating deposition of fat in the abdominal area and body fat percentage. ${ }^{28}$ More studies with larger sample sizes are required to confirm this.

In the present study, LAP was significantly associated with blood glucose, lipid profile, SBP, and DBP. Similarly, in the study by Angelo Vieira et al., which evaluated the correlation between LAP Index and cardiovascular risk factors in hospitalized persons, LAP was significantly correlated with TC, HDL-c,
FBS, and SBP. ${ }^{29}$ Additionally, other researchers found correlations between the LAP index and FBS, HDL-c, and SBP in both healthy subjects and patients with higher cardiovascular risk. ${ }^{30}$ None of these studies found significant correlations between the LAP index and DBP or LDL. The LAP index also increased the risk of T2DM by $30 \%$. Prior studies revealed strong predictive accuracy for MetS. ${ }^{9}$ Overall, the LAP showed stronger relationships with metabolic factors than the other adiposity measures. The LAP index should be recognized as a parameter calculated based on WC and serum triglyceride levels that is strongly correlated with visceral fat. 
In our study, CI had significant correlations with FBS, HbA1c, LDL-c/HDL-c, HDL-c, albuminuria, SBP, and DBP. Likewise, in the study by Ghosh et al., CI was associated with high blood glucose. ${ }^{31}$ Other studies also reported that $\mathrm{CI}$ was associated with triglycerides and TC. ${ }^{27}$ Variables such as weight, height, and abdominal circumference are used to estimate the CI. However, this study suggested that the CI could not predict risk of T2DM. In contrast, the Andrade et al. study identified the $\mathrm{CI}$ as tool for estimating the risk of DM. Our smaller sample size might have contributed to this result. ${ }^{32}$

In the present study; the BAI had significant correlations with FBS, HbA1c, LDL-c/HDL-c, HDL-c, SBP, and DBP. The BAI was developed by Bergman et al., based on $\mathrm{HC}$ and height. ${ }^{33}$ It increased the risk of T2DM up to $20 \%$, even after adjusting for confounding variables such as age, sex, and medications. Similarly, in the study by Oliveira et al., the BAI represented an increase of $8.4 \%$ in the risk of a patient developing T2DM. ${ }^{34}$ Corroborating the findings of Bergman et al. and Lopez et al., our findings confirmed this relationship, highlighting the BAI as an effective parameter in T2DM. ${ }^{33,35}$

However, limitations of the present study include not assessing dietary intakes, the small sample size, and the fact that the case-control study design does not allow for causal inference.

In conclusion, among old and new anthropometric indices, BMI, LAP, and BAI were found to be most associated with T2DM and its related complications. HC and AVI were also found to be sensitive markers. ABSI was not a sensitive marker. So, some of these indices have notable clinical importance for evaluation of T2DM control and could be used in clinical practice selectively.

Abbreviations: BMI; body mass index, CI; conicity index, WC; waist circumference, $\mathrm{HC}$; hip circumference, WHR; waist-to-hip ratio, SBP; systolic blood pressure, DBP; diastolic blood pressure, FBG; fasting blood glucose, HbA1C; glycosylated hemoglobin, TG; triglyceride, CHOL; total cholesterol, HDL; high-density lipoprotein, LDL; low-density lipoprotein cholesterol, VLDL; very low-density lipoprotein, eGFR; estimated glomerular filtration rate, BUN; blood urea nitrogen, $\mathrm{Cr}$; creatinine, $\mathrm{MAP}=$ mean arterial pressure; $\mathrm{PP}=$ pulse pressure; $\mathrm{AIP}=$ atherogenic index of plasma; $\mathrm{ABSI}=$ a body shape index; $\mathrm{AVI}=$ abdominal volume index; $\mathrm{BAI}=$ body adiposity index; $\mathrm{LAP}=$ lipid accumulation product; MetS $=$ metabolic syndrome.

\section{ACKNOWLEDGEMENTS}

Authors declare thanks for the Endocrinology and Metabolism clinic employees of Golestan Hospital of Ahvaz Jundishapur University of Medical Sciences.

\section{REFERENCES}

1. Javid AZ, Bazyar $H$, Gholinezhad $H$, et al. The effects of ginger supplementation on inflammatory, antioxidant, and periodontal parameters in type 2 diabetes mellitus patients with chronic periodontitis under non-surgical periodontal therapy. A double-blind, placebo-controlled trial. Diabetes Metab Syndr Obes. 2019;12:175161. http://dx.doi.org/10.2147/DMSO.S214333. PMid:32021341.

2. Zheng Y, Ley SH, Hu FB. Global aetiology and epidemiology of type 2 diabetes mellitus and its complications. Nat Rev Endocrinol. 2018;14(2):8898. http://dx.doi.org/10.1038/nrendo.2017.151. PMid:29219149.

3. Ahmed T, Haboubi N. Assessment and management of nutrition in older people and its importance to health. Clin Interv Aging. 2010;5:207-16. PMid:20711440.

4. Cardoso CRL, Leite NC, Moram CBM, Salles GF. Long-term visit-tovisit glycemic variability as predictor of micro-and macrovascular complications in patients with type 2 diabetes: the Rio de Janeiro Type 2 Diabetes Cohort Study. Cardiovasc Diabetol. 2018;17(1):33. http://dx.doi.org/10.1186/s12933-018-0677-0. PMid:29477146.

5. Hosseini SA, Alipour M, Zakerkish M, Cheraghian B, Ghandil P. The gene-treatment interaction of FTO-rs9939609 Gene Polymorphism and Epigallocatechin-Gallate intervention on anthropometric indices, fasting blood sugar and insulin resistance/sensitivity in patients with Type 2 Diabetes Mellitus. Iran Red Crescent Med J. 2018;20(12):e82228. http://dx.doi.org/10.5812/ircmj.82228.

6. Park KS. The search for genetic risk factors of type 2 diabetes mellitus. Diabetes Metab J. 2011;35(1):12-22. http://dx.doi. org/10.4093/dmj.2011.35.1.12. PMid:21537408.

7. Dendup T, Feng X, Clingan S, Astell-Burt T. Environmental risk factors for developing Type 2 Diabetes Mellitus: a systematic review. Int J Environ Res Public Health. 2018;15(1):78. http:// dx.doi.org/10.3390/ijerph15010078. PMid:29304014.

8. Hossain P, Kawar B, El Nahas M. Obesity and diabetes in the developing world-a growing challenge. N Engl J Med. 2007;356(3):213-5. http://dx.doi.org/10.1056/NEJMp068177. PMid:17229948.

9. Kahn HS. The lipid accumulation product is better than BMI for identifying diabetes: a population-based comparison. Diabetes Care. 2006;29(1):151-3. http://dx.doi.org/10.2337/diacare.29.01.06. dc05-1805. PMid:16373916

10. Hosseini SA, Aghamohammadi V, Ashtary-Larky D, Alipour $M$, Ghanavati $M$, Lamuchi-Deli N. Jovens iranianas obesas metabolicamente saudáveis têm maior risco de incidência de DCV? J Vasc Bras. 2020;19:e20190106. http://dx.doi.org/10.1590/16775449.190106. PMid:34290747.

11. Hanson RL, Imperatore G, Bennett PH, Knowler WC. Components of the metabolic syndrome and incidence of type2 diabetes. Diabetes. 2002;51(10):3120-7. http://dx.doi.org/10.2337/diabetes.51.10.3120. PMid:12351457.

12. Rios MS. Relationship between obesity and the increased risk of major complications in non-insulin-dependent diabetes mellitus. Eur J Clin Invest. 1998;28(suppl 2):14-8. http://dx.doi. org/10.1046/j.1365-2362.1998.0280s2014.x. PMid:9777322.

13. Abolnezhadian F, Hosseini SA, Alipour M, et al. Association metabolic obesity phenotypes with cardiometabolic index, atherogenic index of plasma and novel anthropometric indices: a link of FTO-rs9939609 polymorphism. Vasc Health Risk Manag. 2020;16:249-56. http:// dx.doi.org/10.2147/VHRM.S251927. PMid:32612360.

14. Marcadenti A, Fuchs FD, Moreira LB, Fuchs SC. Lipid accumulation product index (LAP), body adiposity index (BAI), neck circumference and type-2 diabetes in subjects with hypertension. Arq Bras Cardiol. 2013;101:1-18. 
15. Azizi F, Khalili D, Aghajani H, et al. Appropriate waist circumference cut-off points among Iranian adults: the first report of the Iranian National Committee of Obesity. Arch Iran Med. 2010;13(3):243-4. PMid:20433230.

16. Alberti K, Eckel RH, Grundy SM, et al. Harmonizing the metabolic syndrome: a joint interim statement of the international diabetes federation task force on epidemiology and prevention; national heart, lung, and blood institute; American heart association; world heart federation; international atherosclerosis society; and international association for the study of obesity. Circulation. 2009;120(16):16405. http://dx.doi.org/10.1161/CIRCULATIONAHA.109.192644. PMid:19805654.

17. Alberti KGMM, Zimmet P, Shaw J. International Diabetes Federation: a consensus on Type 2 diabetes prevention. Diabet Med. 2007;24(5):451-63. http://dx.doi.org/10.1111/j.14645491.2007.02157.x. PMid:17470191.

18. Adu EA, Obirikorang C, Acheampong E, et al. Lipid accumulation product (LAP) index as a potential risk assessment for cardiovascular risk stratification among type II diabetes mellitus in a Ghanaian population: a cross-sectional study. Cogent Med. 2019;6(1):1639880. http://dx.doi.org/10.1080/2331205X.2019.1639880.

19. Craig CL, Marshall AL, Sjöström M, et al. International physical activity questionnaire: 12-country reliability and validity. Med Sci Sports Exerc. 2003;35(8):1381-95. http://dx.doi.org/10.1249/01. MSS.0000078924.61453.FB. PMid:12900694.

20. Kengne A-P, Czernichow S, Huxley R, et al. Blood pressure variables and cardiovascular risk: new findings from ADVANCE. Hypertension. 2009;54(2):399-404. http://dx.doi.org/10.1161/ HYPERTENSIONAHA.109.133041. PMid:19470869.

21. Fuhrman DY, Schneider MF, Dell KM, et al. Albuminuria, proteinuria and renal disease progression in children with CKD. Clin J Am Soc Nephrol. 2017;12(6):912-20. http://dx.doi.org/10.2215/ CJN.11971116. PMid:28546440.

22. KnopfholzJ, Disserol CCD, Pierin AJ, et al. Validation of the friedewald formula in patients with metabolic syndrome. Cholesterol. 2014;2014:261878. http://dx.doi.org/10.1155/2014/261878.

23. Rahmanian K, Shojaei M. Relation of Pre-diabetes and Diabetes Mellitus and cardiovascular risk factors: a case-control study. J Jahrom Univ Med Sci. 2017;15(4):1-8.

24. Gomez-Peralta F, Abreu C, Cruz-Bravo M, et al. Relationship between "a body shape index (ABSI)" and body composition in obese patients with type 2 diabetes. Diabetol Metab Syndr. 2018;10(1):21. http://dx.doi.org/10.1186/s13098-018-0323-8. PMid:29568333.

25. Hardy DS, Stallings DT, Garvin J, Gachupin FC, Xu H, Racette SB. Anthropometric predictors of Type 2 Diabetes among white and black adults. In: American Diabetes Association's 75th Scientific Sessions; 2015; Boston. Boston; 2015.

26. Krakauer NY, Krakauer JC. A new body shape index predicts mortality hazard independently of body mass index. PLoS One. 2012;7(7):e39504. http://dx.doi.org/10.1371/journal.pone.0039504. PMid:22815707.

27. Guerrero-Romero F, Rodríguez-Morán M. Abdominal volume index. An anthropometry-based index for estimation of obesity is strongly related to impaired glucose tolerance and type 2 diabetes mellitus. Arch Med Res. 2003;34(5):428-32. http://dx.doi. org/10.1016/S0188-4409(03)00073-0. PMid:14602511.

28. Ehrampoush E, Arasteh P, Homayounfar R, et al. New anthropometric indices or old ones: which is the better predictor of body fat?
Diabetes Metab Syndr. 2017;11(4):257-63. http://dx.doi.org/10.1016/j. dsx.2016.08.027. PMid:27578617.

29. Vieira BA, Sauer P, Marcadenti A, Piovesan CH. Association between LAP Index (Lipid Accumulation Product) and metabolic profile in hospitalized patients. Nutr Hosp. 2015;31(6):2771-4. PMid:26040394.

30. Biyik Z, Guney I. Lipid accumulation product and visceral adiposity Index: two new indices to predict metabolic syndrome in chronic kidney disease. Eur Rev Med Pharmacol Sci. 2019;23(5):2167-73. PMid:30915762.

31. Ghosh A, Bose K, Chaudhuri AB. Association of food patterns, central obesity measures and metabolic risk factors for coronary heart disease (CHD) in middle aged Bengalee Hindu men, Calcutta, India. Asia Pac J Clin Nutr. 2003;12(2):166-71. PMid:12810406.

32. Andrade MD, Freitas MC, Sakumoto AM, et al. Association of the conicity index with diabetes and hypertension in Brazilian women. Arch Endocrinol Metab. 2016;60(5):436-42. http://dx.doi. org/10.1590/2359-3997000000187. PMid:27812606.

33. Bergman R, Stefanovski D, Buchanan T, et al. A better index of body adiposity. Obes. 2011;9(5):1083-9.

34. Oliveira CM, Pavani J, Krieger JE, Alvim RO, Mourão-Junior CA, Pereira AC. Body adiposity index in assessing the risk of type 2 diabetes mellitus development: the Baependi Heart Study. Diabetol Metab Syndr. 2019;11(1):76. http://dx.doi.org/10.1186/ s13098-019-0467-1. PMid:31485273.

35. López AA, Cespedes ML, Vicente T, et al. Body adiposity index utilization in a Spanish Mediterranean population: comparison with the body mass index. PLoS One. 2012;7(4):e35281. http:// dx.doi.org/10.1371/journal.pone.0035281. PMid:22496915.

Correspondence Hadi Bazyar, Student Research Committee, Ahvaz Jundishapur University of Medical Science Golestan Boulevard, Ahvaz, Iran Postal code: 7853167465 Tel.: +989136659629 E-mail: hadibazyar2015@gmail.com

Author information PA and HB - PhD Candidate in Nutrition, Ahvaz Jundishapur University of Medical Sciences. AZJ - PhD in Nutrition, Ahvaz Jundishapur University of Medical Sciences.

LM - Endocrinologist, Ahvaz Jundishapur University of Medical Sciences.

$\mathrm{NH}$ - PhD in Nutrition, Shiraz University of Medical Sciences. RM - MSc in Biochemistry, Ahvaz Jundishapur University of Medical Sciences.

HBB - MSc in Nutrition, Ahvaz Jundishapur University of Medical Sciences.

MZ - MSc in Physiotherapy, Ahvaz Jundishapur University of Medical Sciences.

Author contributions Conception and design: HB, LM, AZJ, PA Analysis and interpretation: $\mathrm{RM}, \mathrm{HB}, \mathrm{HBB}, \mathrm{NH}$ Data collection: RM, NH, MZ, HBB Writing the article: PA, MZ, AZJ

Critical revision of the article: $A Z$ J, $L M$ Final approval of the article*: HB, PA, AZJ, LM, NH, RM, HBB, MZ Statistical analysis: $\mathrm{HB}$ Overall responsibility: $\mathrm{HB}, \mathrm{PA}$

*All authors have read and approved of the final version of the article submitted to J Vasc Bras. 